\title{
Original Research Paper General Medicine \\ CLINICAL PROFILE OF ACUTE KIDNEY INJURY PATIENTS ADMITTED IN MEDICAL INTENSIVE CARE UNIT IN TERTIARY CARE CENTRE
}

\begin{tabular}{ll} 
Dr. Manisha Netam & Senior Resident, Gandhi Medical College, Bhopal \\
\hline Dr. R. S. Jagat & Associate Professor, Gandhi Medical College, Bhopal \\
\hline Dr. Nitin Nahar* & $\begin{array}{l}\text { Assistant professor, Gandhi Medical College , Bhopal *Corresponding } \\
\text { Author }\end{array}$ \\
\hline
\end{tabular}

ABSTRACT Acute kidney injury is one of the major conditions complicating the outcome of hospital admitted patients. Early detection and treatment of AKI can help reduce the mortality to a significant level. The most common conditions succumbing to AKI are hypovolemia, sepsis, drug induced kidney injury, cardiac conditions (reduced cardiac output). Common co-morbid conditions associated are hypertension, diabetes, chronic debilitating conditions like CVA and CAD.

OBJECTIVE- The study aimed at evaluating the clinical profile and co-morbid conditions associated with acute kidney injury in medical intensive care unit in tertiary care setting in central India.

MATERIAL AND MATERIAL AND METHODS- Total 200 patients admitted in medical ICU were selected based on AKIN criteria. pre-exiting conditions like hypertension, diabetes, CAD, CVA were noted. Increase in serum creatinine $>1.5$ times or $>0.3 \mathrm{mg} / \mathrm{dl}$ and decrease in urine output $<0.5 \mathrm{ml} / \mathrm{kg} / \mathrm{h}$ for $6-12 \mathrm{hrs}$ were the criteria for selection. Patients were observed till the time of discharge or death. Data collected was analysed statistically.

RESULTS-Out of the 200 enrolled in the study, 81 patients were female and 119 males. Majority of the patients were found to be under the age group of 35-54 years with a total number of 101. Hypertension was found to be the major co-morbid condition with a patient load of 62 , followed by diabetes, CVA, CAD with a patient load of 30,24and 5 respectively. Sepsis and shock were found to complicating majority of the illnesses and contributing $87.6 \%$ and $67.6 \%$ to the total mortality. Infective conditions like acute gastroenteritis and UTI were the most common causes with a total load of 76 and 15 respectively. Chronic liver disease and hemolytic conditions like malaria were found to contributing a lower patient load but higher mortality. Other causes found to be associated with AKI were found to be post natal cases, snake bite and poisoning.

CONCLUSION- pre- renal causes were found to be the most common causes of AKI. Early recognition and vigorous management is the key to reduce mortality and long term complications.

KEYWORDS : Acute Kidney Injury ,akin Criteria

\section{INTRODUCTION-}

AKI is one of the most important preventable cause of death in hospital admissions including surgical and medical illnesses. AKI complicates 5-7\% of acute care hospital admissions and up to $30 \%$ of admissions to the intensive care unit in developed countries[1]There are various criteria's available that define AKI on the basis of serum urea and creatinine levels and urine output (RIFLE,KIDIGO,AKIN).As different studies have used different criteria's for defining AKI there is limited data regarding the incidence and epidemiology of AKI. The causes of AKI differs according the population involved. In developed countries like USA, the incidence is less as compared to a developing country like India. As the two countries differ in the terms of availability of health services, living condition, and diseases commonly found, the western data may not reflect the true picture for the developing countries.

\section{AIMS AND OBJECTIVES-.}

To Study the clinical profile of patients with Acute kidney injury admitted in medical intensive care unit in a tertiary care centre in central India.

\section{MATERIAL AND METHODS}

Study design

- This is an observational study conducted in the ICU patients over a period of 4 months from June 2016 to nov 2016.

\section{Source of data}

- Patients admitted to medical ICU over the period of study.

\section{Inclusion criteria}

- Patients either with AKI on presentation or diagnosed in hospital stay during the period of study.
Exclusion criteria

- Patients diagnosed with chronic kidney disease

- $\mathrm{h} / \mathrm{o} \mathrm{hemodialysis}$

- h/o kidney transplantation

- Prisoners

- Pregnant females

\section{METHODS}

- The study protocol was approved by institutional ethics committee

- Information was collected through prepared proforma, and informed consent was obtained from each patient/family member. history of smoking, DM, hypertension, cardiovascular event was obtained.

- A complete clinical examination was done. Mean arterial pressure was calculated by the formula of [diastolic pressure + pulse pressure/3].

- Blood samples were collected at the time of admission, after $24 \mathrm{hrs}$ of admission and after $48 \mathrm{hrs}$ of admission. $\mathrm{CBC}$, serum calcium, serum creatinine, serum calcium, serum phosphorus, serum sodium, serum potassium, FBS.

- The patients admitted in ICU were followed up daily until discharge/death from hospital.

- Patients who met the AKIN criteria for AKI any time during their ICU stay were included in the study.

- Urine output was recorded at $6 \mathrm{hrs}, 12 \mathrm{hrs}, 24 \mathrm{hrs}$.

ULTRASONOGRAPHY was performed to see size of kidney, renal parenchymal disease, obstruction by renal calculi and ureteric calculi, hydronephrosis, etc. to rule out CKD.

\section{Data Management Ānd Analysis}

Detailed data was recorded on data collection tool and was entered into MS EXCEL and analysis was done using MS EXCEL and EPIINFO 7. 
RESULT

Table - 1 Genderwise Distribution

\begin{tabular}{|l|l|l|l|}
\hline S.No & GENDER & FREQUENCY & PERCENTAGE (\%) \\
\hline 1 & FEMALE & 81 & 40.5 \\
\hline 2 & MALE & 119 & 59.5 \\
\hline & Total & 200 & 100.0 \\
\hline
\end{tabular}

Table 2: Agewise Distribution Of Patients With

\section{GENDERWISE DISTRIBUTION}

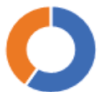

MALE \# FEMALE

Acute Kidney Injury Admitted In Medical Intensive Care Unit

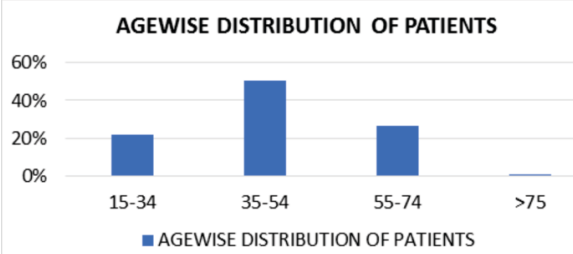

Among the total number of patients, female and males accounts for $40.5 \%$ and $59.5 \%$ respectively. Age group of the patients ranged from 15 to 85 years with majority of the patients found to be under the age group of 35-54 years, with total number of 101 accounting for $50.5 \%$. The mean age of the patient under study was $45.7 \pm 13.23$.

\begin{tabular}{|l|l|l|l|}
\hline S.No & Age In Years & No. Of Patients & Percentage \\
\hline 1 & $15-34$ & 44 & $22 \%$ \\
\hline 2 & $35-54$ & 101 & $50.5 \%$ \\
\hline 3 & $55-74$ & 53 & $26.5 \%$ \\
\hline 4 & $>75$ & 2 & $1 \%$ \\
\hline Total & & 200 & 100 \\
\hline
\end{tabular}

Table 3 Comorbid Conditions Present In Patients With Acute Kidney Injury Admitted In Medical Intensive Care Unit

\begin{tabular}{|l|l|l|l|l|l|}
\hline OUTCOME & CR & DOD & DEATH & TOTAL & $\begin{array}{l}\text { PERCENTAGE } \\
(\mathrm{N}=200)\end{array}$ \\
\hline HTN & 32 & 2 & 28 & 62 & $31 \%$ \\
\hline CVA & 7 & 2 & 15 & 24 & $12 \%$ \\
\hline DM & 19 & 2 & 9 & 30 & $15 \%$ \\
\hline CAD & 2 & 0 & 3 & 5 & $2.5 \%$ \\
\hline
\end{tabular}

Out of the Four co-morbid conditions observed at the time of admission i.e. hypertension, diabetes mellitus, CAD and CVA, hypertension was present in majority of the patients with a total number of 62 patients. Diabetes mellitus was found to be another co-morbid condition accounting for a total number of 30 patients. Cerebrovascular accident was found to be the other major co-morbid condition with a total patient load of 24 followed by coronary artery disease present in 5 patients.

Table 4: Clinical Profile Of The Patients Of Acute Kidney Injury Admitted In Medical Intensive Care Unit

\begin{tabular}{|l|l|l|l|l|}
\hline VARIABLE & Minimum & $\begin{array}{l}\text { Maxim } \\
\text { um }\end{array}$ & Mean & $\begin{array}{l}\text { Std. } \\
\text { Deviation }\end{array}$ \\
\hline Age & 16 & 85 & 45.76 & 13.265 \\
\hline Height & 145 & 168 & 154.20 & 5.954 \\
\hline Weight & 40 & 76 & 54.70 & 6.717 \\
\hline BMI & 17.6000 & 32.9000 & 23.003500 & 2.4524089 \\
\hline SBP & 48 & 116 & 61.81 & 12.151 \\
\hline DBP & 38 & 74 & 46.94 & 9.069 \\
\hline MAP(SBP+2DBP/3) & 16.0000 & 85.3000 & 34.473455 & 18.3301539 \\
\hline FBS & 45 & 257 & 109.34 & 31.811 \\
\hline $\begin{array}{l}\text { S.CREATININE } \\
\text { BASELINE }\end{array}$ & 1.0000 & 14.6000 & 7.607500 & 2.0741272 \\
\hline
\end{tabular}

\begin{tabular}{|l|l|l|l|l|}
\hline $\begin{array}{l}\text { S.CRAETININE } \\
\text { AFTER 24hrs }\end{array}$ & 1.6000 & 14.8000 & 7.097500 & 2.0340182 \\
\hline $\begin{array}{l}\text { S.CREATININE } \\
\text { AFTER 48hrs }\end{array}$ & .7000 & 12.8000 & 6.547449 & 2.1527427 \\
\hline Hb\% & 4.3000 & 14.0000 & 9.332000 & 1.7103516 \\
\hline $\begin{array}{l}\text { S.UREA } \\
\text { (BASELINE) }\end{array}$ & 86 & 376 & 178.33 & 46.831 \\
\hline S. UREA 24 hrs & 84 & 327 & 160.04 & 44.211 \\
\hline TLC & 214 & 32000 & 11203.07 & 4878.324 \\
\hline S. ALBUMIN & 1.2000 & 5.2000 & 3.378500 & .5896833 \\
\hline S. GLOBULIN & 1.6000 & 21.1000 & 3.103000 & 1.3432470 \\
\hline S.potassium & 2.6000 & 6.4000 & 3.623000 & .7317433 \\
\hline S.Na & 109.0000 & 138.0000 & 127.319500 & 4.7987823 \\
\hline HDL(mg\%) & 34 & 74 & 49.19 & 7.502 \\
\hline TG(mg\%) & 94 & 270 & 157.03 & 33.085 \\
\hline S. CALCIUM & 7.8000 & 10.4000 & 9.173500 & .4209916 \\
\hline S. PHOSPHORUS & 2.8 & 4.0 & 3.375 & .3295 \\
\hline
\end{tabular}

\section{DISCUSSION}

Aki is common in patients admitted in the intensive care units. The AKI is often associated with multiple factors, and is known to increase mortality, length of icu stay and hospital stay and in critically ill patient alters the outcome of patients.

Our study was conducted over a period of 4 months in the 54 bedded medical Icu's of our institution.

The demographic analysis of our patients revealed that the average age of our study population was $45.76+-13.26$, and $59.5 \%$ were males. This is similar to the previous studies.[2]

Based on our study decreasing levels of haemoglobin, fall in blood pressure, increasing levels of serum urea and creatinine and total leukocyte count were found to be associated with majority of acute kidney injury cases. Mean age of the patient in our study $45.76 \pm 13.265$, male and female AKI patients were 119 and 81 respectively., mean baseline serum creatinine value was found $7.60 \pm 2.07$, mean baseline serum urea $178.33+46.8$, mean haemoglobin was found to be $9.3 \mathrm{gm} \%$, and mean SBP was $61.8 \mathrm{~mm} \mathrm{hg}$

Even though the facilities and care have improved over the last decade, the overall mortality rates in patients with AKI does not show significant decrease. This may be attributed to the severity of illness at the time of admission and more associated co-morbidities.

\section{REFERENCES}

1. Prakash J, Singh TB, Ghosh B, Malhotra V, Rathore SS, Vohra R, Mishra RN Srivastava PK. Changing epidemiology of community-acquired acute kidney injury in developing countries: analysis of 2405 cases in 26 years from eastern India. Clinical kidney journal. 2013 Feb 6:6(2):150-5.

2. Hsu CY, McCulloch CE, Fan D, Ordonez JD, Chertow GM, Go AS. Communitybased incidence of acute renal failure. Kidney international. $2007 \mathrm{Ju}$ 2;72(2):208-12

3. Xue JL, Daniels F, Star RA, Kimmel PL, Eggers PW, Molitoris BA, Himmelfarb J, Collins AJ. Incidence and mortality of acute renal failure in Medicare beneficiaries, 1992 to 2001. Journal of the American Society of Nephrology. 2006 Apr 1;17(4):1135-42.

4. Susantitaphong P, Cruz DN, Cerda J, Abulfaraj M, Alqahtani F, Koulouridis I Jaber BL. World incidence of AKI: a meta-analysis. Clinical Journal of the American Society of Nephrology. 2013 Sep 6:8(9):1482-93.

5. Kolhe NV, Muirhead AW, Wilkes SR, Fluck RJ, Taal MW. The epidemiology of hospitalised acute kidney injury not requiring dialysis in England from 1998 to 2013: retrospective analysis of hospital episode statistics. International journal of clinical practice. 2016 Apr 1;70(4):330-9.

6. Susantitaphong P, Cruz DN, Cerda J, Abulfaraj M, Alqahtani F, Koulouridis I Jaber BL. World incidence of AKI: a meta-analysis. Clinical Journal of the American Society of Nephrology. 2013 Sep 6;8(9):1482-93.

7. Hoste EA, Clermont G, Kersten A, Venkataraman R, Angus DC, De Bacquer D, Kellum JA. RIFLE criteria for acute kidney injury are associated with hospital mortality in critically ill patients: a cohort analysis. Critical care. 2006 May 12;10(3):R73.

8. Åhlström A, Tallgren M, Peltonen S, Räsänen P, Pettilä V. Survival and quality of life of patients requiring acute renal replacement therapy. Intensive care medicine. 2005 Sep 1;31(9):1222-8.

9. Korkeila M, Ruokonen E, Takala J. Costs of care, long-term prognosis and quality of life in patients requiring renal replacement therapy during intensive care. Intensive care medicine. 2000 Dec 18;26(12):1824-31. 
10. Morgera S, Schneider M, Neumayer HH. Long-term outcomes after acute kidney injury. Critical care medicine. 2008 Apr 1;36(4):S193-7.

11. Schiffl H, Fischer R. Five-year outcomes of severe acute kidney injury requiring renal replacement therapy. Nephrology Dialysis Transplantation. 2008 Apr 11;23(7):2235-41

12. Van Berendoncks AM, Elseviers MM, Lins RL, SHARF Study Group. Outcome of acute kidney injury with different treatment options: long-term follow-up. Clinical Journal of the American Society of Nephrology. 2010 Oct 1;5(10):175562.

13. Waikar SS, Curhan GC, Wald R, McCarthy EP, Chertow GM. Declining mortality in patients with acute renal failure, 1988 to 2002. Journal of the American Society of Nephrology. 2006 Apr 1;17(4):1 143-50.

14. Prescott GJ Metcalfe W Baharani IJ Khan IH Simpson K Smith WC, MacLeod AM. A prospective national study of acute renal failure treated with RRT: incidence, aetiology and outcomes. Nephrology Dialysis Transplantation. 2007 May 21;22(9):2513-9.

15. Ali T, Khan I, Simpson W, Prescott G, Townend J, Smith W, MacLeod A. Incidence and outcomes in acute kidney injury: a comprehensive populationbased study. Journal of the American Society of Nephrology. 2007 Apr $1 ; 18(4): 1292-8$

16. Ratanarat R, Skulratanasak P, Tangkawattanakul N, Hantaweepant C. Clinical accuracy of RIFLE and Acute Kidney Injury Network (AKIN) criteria for predicting hospital mortality in critically ill patients with multi-organ dysfunction syndrome. Journal of the Medical Association of Thailand= Chotmaihetthangphaet. 2013 Feb;96:S224-31.

17. Thomas ME, Blaine C, Dawnay A, Devonald MA, Ftouh S, Laing C, Latchem S, Lewington A, Milford DV, Ostermann M. The definition of acute kidney injury and its use in practice. Kidney international. 2015 Jan 31;87(1):62-73. 